\title{
Embracing supply chain agility: an investigation in the electronics industry
}

\author{
Abstract \\ Purpose: \\ In this research, we aim to identify the antecedents of supply chain agility (SC agility) and \\ how SC agility impacts on firm's performance.

\section{Design/methodology/approach:}

Based on a comprehensive literature review, a conceptual model is proposed. Interrelated hypotheses are tested by structural equation modeling using a dataset collected from 266 Chinese electronics firms.

\section{Findings:}

Initially, we found that supply chain integration and external learning positively influenced SC agility. Secondly, the results indicated that firm's performance is positively impacted by SC agility. Moreover, SC agility also fully mediated the effect of supply chain integration on firm's performance and the effect of external learning on firm's performance.

\section{Research limitations/implications:}

The generalizability of this research sample might be a limitation of this study as it focused on companies operating in the electronics sector. Therefore, future research can adopt other industry sectors samples, such as automobile manufacturing, or other country samples to validate the research model.

\section{Practical implications:}

Our research suggests strategies for supply chain agility which is a core competency of electronics firm in emerging markets. Our findings reveal that the external coordination practices - external learning and supply chain integration are important factors in SC agility. In addition, our findings contribute to the understanding the important role of SC agility in improving firm's performance.

\section{Originality/Value:}

This research examines the impact of two antecedents (i.e. supply chain integration and external learning) on SC agility and is the first empirical research to analyze the mediation effect of SC agility on the relationship between supply chain integration and firm 
performance and the relationship between external learning and firm performance.

Keywords: Agility; Structural Equation Model; Electronics Industry; Integration; Learning; Performance

\section{Introduction}

Over the last decade, increasing attention has been paid to supply chain disruption. The reason is undoubtedly that, with a higher degree of global sourcing, longer supply chains and shorter delivery time requested by the customer, there are more opportunities for disruption and lower tolerance if an interruption occurs (Kleindorfer and Saad, 2005). Disruption can cascade down a supply chain, and downstream firms may eventually shut down their production lines temporarily owing to a lack of critical material or break in the information flow. For example, the Japan earthquake and tsunami in 2011 seriously affected the global market for semiconductors (Kim and Jim, 2011), since Japan is a vital supplier of parts for a wide range of equipment.

To cope with the disruption in supply networks, practitioners and scholars strive to find ways to mitigate the disruption risk. One approach is to increase safety stocks in order to keep production lines moving if inbound transportation is disrupted (Sheffi, 2001). Trkman and McCormack (2009) suggest that preparing backup sourcing can ensure a continuous flow of products/materials. However, these approaches increase the redundancy in a supply system and require large resources for risk mitigation. Braunscheidel and Suresh (2009) propose that the development of supply chain agility (SC agility) can effectively mitigate the disruption risk.

SC agility is widely regarded as a critical element that affects firms' competiveness at the strategic level. This is because firms with SC agility have better performance in responding to unforeseen events. Lee (2004) indicates that agility is a fundamental characteristic of an excellent supply chain. More specifically, Mason et al. (2002: P611) view SC agility as a key element 'to inventory reduction, adapting to market variations more efficiently, enabling enterprises to respond to consumer demand more quickly, and integrating with suppliers more effectively'. In other words, firms need agility in their supply chains to create superior 
business value by managing disruption risks. Recent research efforts have focused on identifying how to achieve SC agility (Swafford et al., 2006; Brauscheidel and Suresh, 2009) and how SC agility impacts on supply chain performance (Swafford et al., 2008; Yusuf et al., 2014). However, some potential antecedents of SC agility have not been fully researched including external learning and SC integration.

This study proposes that external learning is an important antecedent of SC agility. A company with a higher degree of organizational learning is more likely to be characterized as agile (Dumaine, 1994; Antonacopoulou and Chiva, 2007; Bennet and Bennet, 2004). SC agility is an externally focused capability (Swafford et al., 2006), while increased learning from the market, customers and suppliers helps the company to improve its responsiveness to uncertainty. Therefore, in order to identify the role of learning capacity in SC agility, this study focuses on external learning. In external learning, a firm can embrace new knowledge from other organizations and integrate it within its own intelligence. Past studies have pointed out that external learning can improve firms' innovation (Laursen and Salter, 2005; Bao et al., 2012). In the context of supply chain management, learning from the chain members can help an organization to be well-prepared with the most up-to-date knowledge on systems, procedures, technologies and benchmarking in order to respond to market changes quickly and efficiently (Ngai et al., 2011). Although recent research has analysed the role of 'learning orientation' in SC agility, this is a cultural driver that has indirect influence in this regard (Braunscheidel and Suresh, 2009). The impact of external learning on SC agility has not yet been analysed. Therefore, this study strives to fill the research gap by identifying the role of external learning in SC agility.

The study also proposes that SC integration is another under researched antecedent of SC agility. It has already been suggested that a higher degree of SC integration could lead to better firm performance (Frohlich and Westbrook, 2001; Power, 2005; Van der Vaart and van Donk, 2008; Flynn et al., 2010), as it enables a firm to "reach beyond the boundaries of an individual organisation by drawing the suppliers and customer into the value creation process" (Vickery et al., 2003: P523). In this study, we raise the question, does SC integration affect SC agility? In addition, does SC integration directly or indirectly impact on firm performance? In a rapidly changing market environment, companies with a more 
collaborative relationship with supply chain members can respond quicker to market uncertainties. According to Rosenzweig et al. (2003), highly integrated organizations are capable of being more responsive to demand and changes in the highly competitive business environment (i.e. uncertainties in technology and regulations). In addition, prior studies have investigated the direct effect of SC integration on firm performance (e.g. Flynn et al., 2010) and test the indirect effect of it on firm performance (e.g. Vickery et al., 2013). However, to the best of our knowledge, no attempt has yet been made to empirically test the mediation role of SC agility in the relationship between SC integration and firm performance.

We examine the development of SC agility in the context of the Chinese electronics industry. SC agility is particularly important in this industry, because of the product characteristics. First of all, the short life cycle of the products causes demand uncertainty and challenges inventory control. In addition, the products are complex, and require a wide range of supply materials. Finally, given the increasing importance of product individualization, the lot-size of supply materials is small. These three factors all present a challenge to supply chain management and require SC agility.

Since the 1990s, China has taken advantage of ample labour resources, low land costs, and enormous market demand, to become a global centre of electronics manufacturing. The electronics industry has undergone rapid growth, particularly in the Pearl River Delta region (PRD) in Guangdong province, home to the earliest developed and largest electronics industry cluster in China (Yang et al., 2013). According to Humphreys et al. (2011: P138), the PRD also represents the 'maquiladora' concept, that is, 'a form of international operation that involves a flexible, agile and inexpensive mode of operation, in conjunction with the need to provide an effective supply chain network'. The research of Humphreys et al. (2011) provides a valuable insight with regard to improving the buyer-supplier performance through supplier development activities in the electronics industry context. With specific reference to the Chinese electronics industry, this research extends the previous work by investigating the antecedents of SC agility and their impact on firms' performance. To do so, we propose a conceptual model and adopt a structural equation modelling (SEM) approach to test the relationships between supply chain integration and external learning, which impact on SC agility and firms' performance, using data collected from 226 electronics manufacturing 
firms in the China PRD region.

This paper is organized as follows. Following a review of the literature in section 2, the model and hypotheses development are described in section 3. The research methodology and model testing are addressed in section 4 . Section 5 provides discussion of the results. Finally, section 6 provides managerial implications, describes limitations of the research, and suggests directions for future research.

\section{Literature Review}

In order to establish the theoretical model, this section will review the research to date on SC agility, external learning and SC integration.

\subsection{Supply Chain Agility}

The concept of SC agility is derived from and encompassed within the broader and multidimensional concept of organizational agility (Swafford et al., 2006). Therefore, it is necessary to clarify the meaning of 'agility' before moving to focus on the supply chain context. Agility has been regarded as the comprehensive integration of all the business elements and a firm's competitive bases, such as speed, flexibility, innovation, quality and profitability (Kidd, 1994; Yusuf et al., 1999). It has been more narrowly defined as the ability to complete rapidly the transformation between different assemblies manufacture (Quinn et al., 1997). According to Fliedner and Vokuka (1997), agility is an organizational ability to produce a comprehensive range of products efficiently with low cost and high quality, and built to individual customer specification. Nagel and Dove (1991) note that, as a business concept, agility is related to a flexible manufacturing system. From the perspective of manufacturing management, Sharifi and Zhang (1999) state that agility is an ability to deal with unexpected change and to benefit from changes as opportunities; indeed, these are the two main dimensions of the agility concept. However, Kidd (2000) argues that an agile enterprise should not only respond to uncertainties quickly, but should also adapt rapidly to changes and opportunities within the processes and structures. 
In order to survive in the fickle business environment, firms should not only operate with agility themselves, but should also be agile within the supply chain relationship. Dove (1996) pioneers the concept of agile supply-chain management. Although he does not provide a formal definition of SC agility, he states that agility is concerned with change proficiency, which is the competency in which an adaptive transformation occurs, and an agile supply chain should adapt adequately to different kinds of changes through virtual enterprise partnering, production outsourcing and component supplier networks (Dove, 1996). Swafford et al. (2006) define SC agility as the capability of the supply chain to adapt or respond quickly to the dynamic and unpredictable business environment.

According to Braunscheidel and Suresh (2009) and Chiang et al. (2012), SC agility can be measured as a second-order construct constituted by three common first-order constructs: demand response, customer responsiveness and joint planning. Both demand response and customer responsiveness measure a firm's responsiveness in the dynamic business environment, while joint planning is the key driver of risk mitigation and of leveraging the threat of market uncertainty. Christopher (2000) argues that SC agility is an ability of firm to rapidly responds to the market. Therefore, as a dimension of SC agility, demand response can be defined as the ability of firm to make efficient response to changes in demand (Christopher, 2000). In addition, according to van Hoek et al. (2001) and Swafford et al. (2006), "SC agility is all about customer responsiveness and mastering market turbulence". As a part of the SC agility, customer responsiveness is defined as the capability of firm to rapidly meet the changes in customers' needs and wants (Tunc and Gupta, 1993; Chen et al., 2004). Moreover, in accordance with the van Hoek (2001) and Brauscheidel and Suresh, (2009), the importance of joint planning in purchasing, logistics and production with supply chain members should be regard as a dimension of the SC agility. To sum up, in this study, SC agility is regarded as a firm's ability to transform the threats of market uncertainty and supply chain disruption into competitive opportunities by increasing visibility in inventory and demand levels, and satisfying various customer need with speed and flexibility (Dove, 1996; Christopher, 2000; Prater, 2001; Van Hoek et al., 2001; Brauscheidel and Suresh, 2009; Ngai et al., 2011). 
Most of the previous work in this area focuses on building then verifying the conceptual models used to describe the elements or antecedents of SC agility. Some studies identify the influence of SC agility on organizational performance. Tolone (2000) suggests that real-time and asynchronous collaboration technology is crucial to allow manufacturers to increase their SC agility. Using a variety/variability and volume matrix, Christopher (2000) indicates that an agile supply chain is needed when demand is volatile and the requirement for variety is high. Four distinguishing characteristics are suggested as the routes to agility, namely market sensitivity, network orientation, process integration, and virtualness (Christopher, 2000; Christopher et al., 2004).

Swafford et al. (2006) develop a model based on the Supply-Chain Operations Reference (SCOR) model (Supply Chain Council, 2004), and find that SC agility is positively impacted by the flexibility of sourcing, manufacturing, and distribution/logistics. Agarwal et al. (2007) use interpretive structural modelling (ISM) to determine that, ' $\mathrm{SC}$ agility relies on customer satisfaction, quality improvement, cost minimization, delivery speed, new product introduction, service level improvement, and lead-time reduction'. Swafford et al. (2008) propose a conceptual framework of SC agility to investigate the relationships among SC agility, supply chain flexibility, information technology integration and competitive business performance. Their findings indicate that supply chain flexibility directly impacts SC agility, while IT integration has an indirect influence. Ngai et al. (2011) broaden the scope of antecedents to the supply chain competencies level, comprising IT competence, operational competence, and management competence. Through a multi-cases study, they conclude that SC agility is the competitive capability of an organization, which is affected by the supply chain competence.

Although the existing literature has identified different dimensions to and characteristics of agility (Christopher, 2000; Christopher and Lowson, 2004), and various antecedents (Prater et al., 2001; Swafford et al., 2006; Agarwal et al., 2007; Braunscheidel and Suresh, 2009; Ngai et al., 2011), to date there has been few investigation of SC integration and external learning as direct antecedents of SC agility. External learning, as a key component of supply chain competency, has a positive impact on customer satisfaction and a more market-focused supply chain (Spekman et al., 2002). As such, external learning might act as a driver of SC 
agility, which requires faster customer response and demand response in the supply chain. In addition, this study argues that IT integration, internal and external integration and process integration as mentioned previously could be conceptualized as SC integration in order to directly measure the influence on SC agility. Therefore, this study will concentrate on two proposed antecedents of SC agility: SC integration and external learning.

\subsection{Supply Chain Integration}

There have been studies demonstrating the value of SC integration on improving the effectiveness of the supply chain (Frohlich and Westbrook, 2001; Power, 2005; Van der Vaart and van Donk, 2008; Flynn et al., 2010). SC integration aims to establish the strategic collaboration with the chain members (Zhao et al., 2008). According to Huo (2012: P596), the SC integration is "the degree to which a company can strategically cooperate with supply chain members to manage the external and internal organsiational process to provide customers the maximum value with low costs and speed". Frohlich and Westbrook (2001) indicate that SC integration includes two types: forward delivery integration and backward information integration. In this study, the definition of SC integration follows the definition put forward by Power (2005) "to elevate the linkages within each component of the chain, to facilitate better decision and to get all pieces of the chain to interact in a more efficient way" (Clancy, cited in Putzger, 1998, p. 55). In an integrated supply chain, there are three essential elements, namely, management information systems (focus on the flow of finance and information management), inventory management (focus on the flow of product and material) and supply chain relationships (focus on managing the relationship among the chain members) (Nichols, 1999; Power, 2005).

Although many research identified the impact of different aspects of SC integration on firm performance and supply chain effectiveness, there is a lack of studies on investigating its impact on SC agility. SC integration has been identified its strategic role on financial performance (Kim, 2006; Flynn et al., 2010; Zhao et al., 2013), operational performance (Armistead and Mapes, 1993; Devaraj et al., 2007), supplier performance (Zsidisin et al., 2015) and firm's responsiveness (such as on-time delivery performance, flexibility to change volume) (Danese et al., 2013). Moreover, researchers also investigated the moderation role 
and the mediation role of the SC integration on various relationship between management practices and performance. For example, Narasimhan and Kim (2002) identify the moderation role SC integration strategy in the relationship between diversification and firm performance. In addition, Droge et al. (2012) demonstrate how supply chain integration mediates the effects of product and process modularity strategies on firm's service performance. Nevertheless, the investigations of indirect effect of SC integration on firm performance were not consistent and sufficient (Kim, 2009).

\subsection{External Learning}

Originating in the traditional theory of resourced-based view, the literatures of knowledgebased view emphasize the strategic value of organisational knowledge (Conner, 1991; Grant and Baden-Fuller, 1995; Huang et al., 2008). According to Sveiby (2001), knowledge is "dynamic, personal and distinctly different from data and information". It is a kind of intangible assets of firm that can create tangible values. The theory of knowledge-based view strives to analyse the mechanisms that lead a firm to acquire and create organisational knowledge (Spender, 1996; Nonaka, 1991, 1994; Huang et al., 2008). Drawing on the knowledge-based view theory, the external learning can be defined as the knowledge acquisition and creation by interorganisational learning through jointly solving problem with customers and suppliers (Huang et al., 2008; Schroeder et al., 2002). A close collaboration with supply chain members can provide a basis for the company to share tacit knowledge (Linderman et al., 2004). Then, the tacit knowledge generated by external learning can be transferred as the explicit knowledge of firm (Nonaka, 1994).

In the context of supply chain, the external learning could comprise two components: learning from upstream suppliers and learning from downstream customers. According to Bierly and Daly (2007), the efficiency of learning from customers can predict the innovation speed of a firm. For example, company can improve the product design or service by learning the feedback from the customers. Compare with the professional advices (e.g. advices from consultancy firm), Matting et al. (2004) stress, the ideas from customers are more innovative. Moreover, Madhok and Tallman (1998) state that the tacit knowledge created with the customer is not easy to be duplicated. The external learning can also benefit from a long term 
relationship with the suppliers. The occurrence of external learning from suppliers though many forms, like supplier routine involvement in new product or process design and product quality improvement (Gerwin, 1993; Schroeder et al., 2002).

\section{Research Framework}

Insert Figure 1 here.

Our conceptual model, shown in Figure 1, includes SC integration, external learning, SC agility and firm performance. Typically, SC agility was constructed as a second-order factor that contains three dimensions: demand response, customer response, and joint planning. This study proposes that external learning and SC integration positively impact SC agility. Finally, firm performance is positively impacted by SC agility.

\subsection{SC integration and External Learning}

Li and Lin (2006) argue that excellent supply chain partnership based on strategic supply chain coordination can ensure accurate and quality information through the supply chain. As presented in Figure 1, we propose a relationship between SC integration and external learning. According to Schroeder et al. (2002), an unduplicated knowledge can be created through sustainable relationships with customers (Madhok and Tallman, 1998; Ward, 1995) and long-term relational contracting with suppliers (Gerwin, 1993). Love et al. (2002) argue that organizations should consider developing long-term relationships that will allow each party to form learning alliances. Through integrating partners in the supply chain, firms can establish a cooperative learning environment that may make knowledge sharing seamless. Therefore, this study hypothesizes that SC integration positively influence external learning:

H1 Supply chain integration positively impacts on external learning. 


\subsection{Antecedents of SC Agility}

The goal of supply chain integration is to provide customers with maximum value at low cost with high speed, by means of the efficient flow of resources and information within the supply chain (Flynn et al., 2010). When a firm faces changes in competition, its strategically collaborative relationship with supply chain partners can help it to respond quickly and to engage in information sharing. In addition, highly integrated organizations acquire competitive advantage in terms of being more responsive to frequent changes in competition, technology and regulations, and have higher information visibility and operational knowledge (Rosenzweig et al., 2003). Therefore, we expected that the SC integration could influence all three dimensions of SC agility, namely, demand response, customer response, joint planning. For example, according to Krause and Scannell (2002), the closing working relationship is a required foundation for joint planning. Therefore, joint planning might be positively improved by the SC integration. Ngai et al. (2011) carry out a multiple-case research study, and find that there is a strong connection between integration and agility. Moreover, Gligor (2014) indicates that the integration of demand and supply enable company to achieve the SC agility. Overall, SC integration is regarded as the significant predictor of SC agility. Thus, we hypothesize:

H2a Supply chain integration positively impacts on SC agility.

A firm with SC agility should adapt or respond quickly to the dynamic and unpredictable business environment. A company that is continually learning then accumulating knowledge and information about the marketplace from its supply chain members can point the way toward an agile supply chain (van Hoek et al., 2001; Gligor and Holcomb, 2012). According to Day (1994), through learning about customers, competitors, and the market situation, a company can have a better chance of sensing and acting on uncertainties and trends in the marketplace. From a problem-solving perspective, learning from chain members can help an organization to be well-prepared with the most up-to-date knowledge on systems, procedures, technologies and benchmarking to respond to market changes in a timely and efficient manner (Ngai et al., 2011). External learning enables firms to keep pace with the competitive 
and uncertain environment. Hence, external learning might be expected to influence the responsiveness of a firm, such as the customer response and demand response, which are also the elements of the SC agility. Accordingly, it is hypothesized that:

H2b External learning positively impacts on SC agility.

\subsection{Supply Chain Agility and Firm Performance}

According to the Resource Based View (RBV), the unique capability of a firm, which can be transferred from various tangible and intangible resources, is the primary driver of organizational performance and competitive advantages (Wernerfelt, 1984). While firms compete on the basis of their resources, they sustain a competitive position through the difference in their resources (Barney, 1991). SC agility is an organization's competitive capability, relying on various competencies, for responding quickly and adapting to market changes and customers' requirements. In this case, from the perspective of RBV, SC agility is a distinctive capability of a firm, based on different resources and leading to outstanding performance. As the capability of an organization to sustain its competitive position, SC agility cannot easily be imitated. In relation to $\mathrm{RBV}$, the capability of SC agility is appropriate not only for large-scale companies, but also for any-scale companies without high investment requirement (Ngai et al., 2011). In the oil and gas industry, SC agility has a significantly positive influence on business performance, including net profit, market share, customer loyalty, and performance relative to competitors (Yusuf et al., 2012). Similarly, Swafford et al. (2008) indicate that the higher the SC agility, the higher the competitive business performance. However, using the secondary data to access the firm's financial performance, Gligor et al. (2015) empirically find that there is no direct relationship between SC agility and firm's financial performance. In order to examine the inconsistent findings, we hypothesize:

H3 SC agility positively influences firm performance. 


\subsection{The mediating role of Supply Chain Agility}

In the literature, there has been support of the direct effect of SC integration on firm performance (such as Frohlich and Westbrook, 2001; Flynn et al., 2010; Zhao et al., 2013). Previous studies demonstrate the proposition of external learning (or inter organisational learning) could directly impact on firm performance (Dyer and Nobeoka, 2000; Tippins and Sohi, 2003; Alegre and Chiva, 2008). Although existing studies apply statistical method (such as regression analysis and SEM) or case study approach to verify the direct impact of external learning and SC integration on firm performance, very few of them employ an analysis to investigate their direct and indirect effect in a holistic model. Moreover, most of the related literatures focus on identifying the direct causality of SC agility (i.e. what influence on SC agility and what impact by SC agility), but few of them has tried to posit the mediation role of SC agility in potential relationship between the management practice and firm performance.

Apparently, a seamless supply chain network would help companies to improve their firm performance, because the transactional costs could be lower (Cao and Zhang, 2011). Nevertheless, an integrated supply chain without agility (such as customer responsiveness and demand response) might bring risks to companies in coping with the turbulence from market. We argue that the SC integration is not capable of providing the benefits to the firm performance until enhancing SC agility. Specifically, SC agility can utilize the advantages of $\mathrm{SC}$ integration, then transfer them to the competitive advantages of firms. For example, implementing the SC integration might help firm to improve the efficiency of joint planning, customer responsiveness and demand response in which are the components of SC agility that might enhance firm performance. Therefore, we contend SC integration influence on firm performance through SC agility.

In addition, firm performance (in terms of the probability and ROI) could be enhanced by the learning ability of firm (Day, 1994a; Slater and Narver, 1995; Tippins and Sohi, 2003). According to Day (1994b) and Slater and Naver (1995), firm can better understand the market trends by learning about customers, competitors and regulators and therefore lead to outstanding financial performance. However, we suggest that the effect of external learning 
on firm performance might be indirect. Moreover, the knowledge created from external learning can transform as the capability of firm (e.g. SC agility), then determine the superior performance of firm. For instance, the knowledge learning from customers (such as feedback of product quality performance) could increase the customer responsiveness in which drive increased firm performance. Thus, the following hypotheses are set as follow:

H4a The SC agility mediates the relationship between SC integration and firm performance $\mathrm{H} 4 \mathrm{~b}$ The SC agility mediates the relationship between external learning and firm performance

\subsection{Control Variable}

Aside from the potential antecedents, external learning and SC integration, company size may influence SC agility. In addition, company size may also impact the firm performance. According to Zhao et al. (2011), larger companies may have more resources to implement various supply chain activities. Similarly, compared with the smaller firm, larger companies may have an advantage in achieving SC agility. Hence, the introducing of company size in our model can control for organisational structure, managerial behaviour and resources available for a particular plant (Hendricks and Singhal, 2001, Kassinis and Soteriou, 2003).

\section{Empirical Study}

\subsection{Survey Instrument Development and Deployment}

In order to adopt an appropriate measurement instrument, we undertook a thorough literature review to identify the scales used in past research. The questionnaire items were reviewed by three academics and three practitioners to ensure content validity. A list of our survey items and their sources is provided in Table 2. A 7-point Likert scale was adopted to indicate the extent to which respondents agree or disagree with each question item, where $1=$ strongly disagree and $7=$ strongly agree.

Since our target respondents were directors and managers in Chinese firms, the questionnaire was translated into Chinese. We consulted a leading scholar in China to ensure the 
measurement items in Chinese reflected the business environment faced by the Chinese manufacturing industry. According to the steps proposed by Brislin (1980), the Chinese questionnaire was subsequently translated back into English by a third party translator to make sure that the measurement items accurately reflect the original meanings.

\subsection{Data Collection}

The target respondents were directors or senior managers in manufacturing firms. Data were collected through a survey of China PRD region electronics firms.

The research objectives are best achieved by obtaining responses from relevant managers and presenting a diverse set of external coordination practices (such as SC integration, external learning) geared to solving quality and safety problems. Three email contacts were made with each of the potential informants, including a pre-notice, the primary invitation letter along with a survey link and an endorsement letter from Guangdong Institute of Scientific \& Technical Information (GISTI). A merged contact list comprising a list purchased from a marketing company and list provided by GISTI containing contact information of 4038 firms dealing in electronics manufacturing in the China PRD region was used in this research. The survey questionnaires were sent via email over 12 weeks, and then a follow-up email/call was sent to remind the key informants to respond. In total 320 survey questionnaires were received, representing a $7.9 \%$ response rate. However, only 266 copies of the questionnaire were valid, as 54 responses were incomplete (hence a $6.6 \%$ usable response rate). Table 1 shows the information of the respondents. It should be noted that our research model includes only the reflective constructs.

Insert Table 1 here.

In this research, we also evaluate non-response bias, by assessing significant differences between the early and late arriving surveys (Swafford et al., 2006). Although there is another method to evaluate non-response bias through testing the significant differences between 
respondents and non-respondents, the non-respondents in our survey did not provide the information of firm size and annual sales. Therefore, this research only compares between the early respondents and later respondents. According to the classic procedure suggested by Armstrong and Overton (1977), researchers can conduct the $\chi^{2}$ tests to show that respondent and non-respondent firms share the same distribution of organizational size and annual sales at $p<0.05$. We employ the $\chi^{2}$ tests to compare the first 50 questionnaires received (early responses) and the last 50 questionnaires received (late responses) (Swafford et al., 2006). The result of the $\chi^{2}$ tests indicates that there are no statistical differences at $p<0.05$ when comparing organizational size $(p=0.178)$ and annual sales $(p=0.239)$ between early respondents and late respondents.

In this study, the common method bias may exist, as all the measures use 7-point Likert scales and responses are from a single informant from each organization (Podsakoff et al., 2003, Doty and Glick, 1998). To test the common method bias, we employ the Harman's single factor test (Harman, 1967; Podsakoff and Organ, 1986). Kassinis and Soteriou (2003) suggest that if the common method variance existed, a general factor could account for most of the variance in the factor analysis, which means that a single factor would emerge from a factor analysis of all questionnaire items. According to the factor analysis of all the questionnaire items, seven factors with eigenvalues greater than 1.0 that accounted for $57.8 \%$ of the total variance. However, the first factor only accounted for $22.7 \%$ of the total variance. Therefore, the common method variance was not a serious issue in this research.

\subsection{Measurement Model}

In this research, the measurement scales for the constructs were majorly developed based on the prior studies. This model consists of four major components: SC agility, External Learning, SC Integration and Firm Performance. SC agility is a second-order latent variable with three dimensions: Joint Planning, Customer Response and Demand Response.

The confirmatory factor analysis (CFA) was adopted to assess the reliability and validity of our constructs. The Cronbach's Alphas were generally greater than 0.7 indicate satisfactory 
reliability (Fornell and Larcker, 1981). Although the value of Cronbach's $\alpha$ in customer response is below 0.7, the construct is still acceptable, as the value is above 0.6 (Hair et al., 2006). According to Brown (2006), the results of CFA can provide evidence of the convergent and discriminant validity of theoretical constructs. The results of CFA for seven related constructs with each item descriptions are presented in the Table 2. If the comparative fit index (CFI) is greater than 0.90 , the value of $\chi^{2} / d f$ is less than 5 , and the root mean square error of approximation (RMSEA) is less than 0.08 , the measurement model is considered to be acceptable. We used AMOS 22 to conduct the CFA. Results of the CFA indicate good fit for the measurement model with Chi-square of 301.443 and degree freedom of 154 , with CFI $=0.921$, and RMSEA $=0.060$. In addition, the incremental fit index (IFI) of 0.930, the non-normed fit index (NNFI) of 0.913 and goodness-fit-index (GFI) of 0.897 also indicate the acceptable model fit (Browne and Cudeck, 2003). Results in Table 2 indicate that item loading were all positive and greater than 0.50 and their critical ration were all significant at $p<0.01$ level, which means that the convergent validity is supported (Gerbing and Anderson, 1988, Bollen, 1989). The AVEs for the constructs are all above 0.40, which indicate the acceptable reliability levels (Kristal et al., 2010, O'Leary-Kelly and Vokurka, 1998, Fornell and Larcker, 1981). To assess the discriminant validity, this study adopts the criterion suggested by Chin (1998): the square root of AVE for each construct should be larger than the inter-construct correlations. As shown in Table 3, the diagonal elements with bold face, which are the square root of AVE, are larger than the inter-construct correlations, which mean that all the results meet the guidelines.

Insert Table 2 here.

Insert Table 3 here.

Insert Figure 2 here. 
In addition, as shown in the Figure 2, we assessed the CFA for the second-order factor in our model (i.e. SC agility). The fit indices of measurement model for the first-order latent variable indicate acceptable fit $\left(\chi^{2} / d f=2.893, \mathrm{IFI}=0.937, \mathrm{NNFI}=0.900, \mathrm{CFI}=0.936\right.$, RMSEA $=0.085)$. In the structural model for the second - order factor, the significant standardized path coefficient between the first-order constructs and higher-order construct confirmed the proposed structure of SC agility (Figure 2). In addition, the target $(T)$ coefficient of $99.33 \%$ indicates the efficacy of second-order models (Marsh and Hocevar, 1985, Cao and Zhang, 2011). Therefore, the results support the SC agility second-order construct.

Insert Table 4 here.

\subsection{Structural Model}

In this section, we employ AMOS 22 to test the hypothesized model. The results of the structural model are presented in Figure 2. The goodness-of-fit test for the structural model is acceptable, with $\chi^{2} / d f=1.844=180$, IFI $=0.928$, GFI $=0.894$, NNFI $=0.915$, and RMSEA $=0.056$. Therefore, the model indices were all satisfied the recommended values for the goodness-of-fit tests.

Insert Figure 3 here.

First, the standardized path coefficient between SCI and external learning is 0.318 and statistically significant at the level of 0.01 , which therefore supports H1. Second, as can be seen from Figure 2, the standardized path coefficient between SCI and supply chain agility is significant $(0.45 ; p<0.01)$. Therefore $\mathrm{H} 2 \mathrm{a}$ is supported. Likewise, the standardized coefficient of path from external learning to supply chain agility is also highly significant (0.47; $p<0.01)$. Thus H2b is supported. External learning and SCI jointly explain $55 \%$ of 
variance in SC agility $\left(R^{2}=0.55\right)$. Third, our findings show that the standardized path coefficient between SC agility and firm performance is highly significant $(0.46 ; p<0.01)$, providing support to H3. To be noted, the effect of company size, as control variable included in the model, is insignificant on firm performance and SC agility.

Insert Figure 4 here.

Insert Figure 5 here.

In addition, we employed a mediation analysis to examine the mediation effect of the antecedents of SC agility on firm performance. In accordance with Baron and Kenny (1986), we first remove the construct of SC agility from the structural model. Here we observe a link between the SC integration and firm performance. We found that the direct path from SC integration to firm performance is significant $(0.268 ; p<0.01)$. Next, the results of the structural model (Figure 3) reveal that there is a significant relationship between the outcome variable (firm performance) and the mediator variable (SC agility), as well as significant relationship between the independent variable (SC integration) and mediator variable (SC agility). These results are satisfied the requirements of mediation tests (Baron and Kenny, 1986). In the last test of the mediation, we establish the direct link (i.e. SC integration to firm performance) in the full structural model (Figure 4). Interestingly, direct link from SC integration to firm performance is not significant. Following the same procedure, we conduct an analysis on investigating the mediation role of SC agility in the relationship between external learning and firm performance. We identified a significant direct path $(0.278 ; p<$ 0.01) from external learning to firm performance without establishing the link between SC agility and firm performance. However, the direct link from external learning to firm performance change to be insignificant after added the link from SC agility to firm performance. According to the Baron and Kenny (1986) tests, the mediation analysis suggests 
that SC agility fully mediates the effects of supply chain integration and external learning on firm performance.

To further examine the mediation effect of SC agility, we also assessed the Bootstrapping method to analyse mediation processes (Bollen and Stine, 1990; Saldanha et al., 2013). The results of the Bootstrapping analysis are provided in Table 5, where contains the direct, indirect effects for the mediated relationship model and confidence interval for each structural path. If the confidence interval for indirect effects of SC integration and external learning on firm performance does not contain zero, the mediation effects are supported (Rungtusanatham et al., 2014). The results indicate that the mediation effect of SC agility is both confirmed as the confidence interval for the indirect effect does not contain zero $[0.1265,0.441]$ and $[0.096,0.727]$. Therefore, both of $\mathrm{H} 4 \mathrm{a}$ and $\mathrm{H} 4 \mathrm{~b}$ are supported.

Insert Table 5 here.

\section{Discussion}

The major aim of this research is to establish a conceptual model for investigating the antecedents of SC agility and the impact of SC agility on firm performance in China's electronics industry. We conceptualize SC agility as a second-order factor consisting of customer response, demand response and joint planning. The model reveals that the external coordination practices (i.e. the management practices that need to be cooperated with the external chain members) - external learning and SC integration are antecedents of SC agility. In addition, SC agility enhances firm performance.

Our results reveal that supply chain integration contributes to external learning. In order to respond to market changes in a timely and efficient manner, firms should be well-prepared with the most up-to-date knowledge from their external partners through active learning (i.e. actively learn from chain member through solving problems together). Accordingly, due to the mitigation of asymmetric information, we find that the level of external learning is 
affected by the extent of SC integration.

Our research findings indicate that supply chain integration has positive impacts on SC agility. This result is also consistent with the literature (Braunscheidel and Suresh, 2009; Christopher, 2000; van Hoek et al., 2001). As expected, supply chain integration plays an important role in achieving SC agility, because companies with supply chain integration have the advantage of being more responsive to frequent changes in competition, technology and regulations, and have higher visibility and operational knowledge (Rosenzweig et al., 2003). Moreover, our findings show that external learning is positively associated with SC agility. In other words, if a company has a higher level of external learning, it is easier for it to achieve SC agility. Although research of SC agility attempts to adapt the 'learning orientation' in the conceptual model as organizational orientation (Braunscheidel and Suresh, 2009), there is limited investigation of the direct interface between organizational learning capacity and SC agility. In accordance with the study of Schroeder et al. (2002), our research narrows down the organizational learning capacity as external learning that focuses on the supply chain context. Our empirical results support the notion that firms with better external learning capacity are more likely to respond to market uncertainty with speed and flexibility (i.e. SC agility).

In terms of firm performance, this study finds that SC agility has a significantly positive impact. This result further confirms the work of Yusuf et al. (2012), who demonstrate the importance of SC agility on firm performance from the perspectives of turnover, net profit, market share, customer loyalty, and performance relative to competitors in the context of the oil and gas industry. Using a different analytical method and different evaluating scales, our study validates this significant relationship in the electronics industry.

In addition, this study suggests that SC agility has full mediating effect on the relationship between SC integration and firm performance. SC agility helps supply chain integration to improve firm performance. The result of the direct effect analysis on the relationship between SC integration and firm performance also supports the extant supply chain integration literature, which states that there is a significantly positive relationship between supply chain integration and organizational performance (e.g. Kim, 2009; Rosenzweig et al., 2003; Flynn 
et al., 2010; Frohlich and Westbrook, 2001). Nevertheless, we provide the new insight, not previously reported in the literature, that although supply chain integration contributes to better firm performance, the full mediation effect of SC agility in this causation cannot be ignored. The finding suggests that implementing the SC integration could enhance the SC agility along dimensions such as demand response, customer response and joint planning, which as above drives increased firm performance.

Since the direct path from external learning to firm performance was insignificant, through SC agility, the effect of SC agility is fully mediated. In other words, the knowledge created by external learning from chain members through jointly problem solving will not necessarily translate directly into firm performance. The significant result of direct effect of external learning on firm performance, without considering the effect of SC agility, is consistent with the previous studies in the field (e.g. Day, 1994a; Slater and Narver, 1995; Tippins and Sohi, 2003). Seemingly, firm that is able to learn from suppliers and customers can stand a better chance of understanding the market trends and therefore lead to a better performance (Tippins and Sohi, 2003). However, we argue that it might ignore a mechanism of how company transfer knowledge to the capacity (e.g. SC agility). According to the findings of the mediation analysis, we suggest that external learning must first have an impact on demand response, customer responsiveness and joint planning, and they are those the elements of SC agility that then improve the firm performance. For example, through learning from its customers a company may be capable of enhancing its customer responsiveness which in turn can lead to superior firm performance.

Furthermore, we also look at whether there exist synergy effect and complementarity of SC agility on firm performance. According to Tanriverdi and Vendkatraman (2005), the association between resource relatedness and firm performance can be used to examine the synergy effect, where firm value can be improved by resource relatedness. In this study, we conceptualize SC agility as a second order model comprising the three components of customer response, demand response and joint planning. These three components of SC agility can share common resources to achieve the synergy effect. In this case, the joint operation cost of SC agility should be less than the sum of individual operation cost of each component. For instance, there are some common points between demand response and 
customer response such that the two practices can share the operation costs. Moreover, in accordance with the theory of complementarity, the added value of resource combination should be greater than the sum of individual practice added value (i.e. value $(A, B)>$ value (A)+value (B)) (Mishra and Shah, 2009). For example, in the SC agility we conceptualize, there is a complementary effect in joint planning and customer response. Specifically, a company will have better joint planning with chain members, such as the customers, when it is involved in the activity of improving the responsiveness for the customers.

In order to investigate the direct effect of the first order of SC agility, we further test our structural model by removing the second-order factor (i.e. SC agility). As reported in Table 6, in the direct-effect model, not all the structural links between SC agility components and firm performance are significant. However, in the structural model shown in Figure 2, the structural link between SC agility and firm performance is highly significant. This indicates that complementarity exists in the second-order model of SC agility, where it positively impacts on firm performance. The comparison of two different models also further supports the theory of complementarity (Tanriverdi and Venkatraman, 2005; Mishra and Shah, 2009).

Insert Table 6 here.

According to RBV, SC agility can be viewed as the unique resources of a company, which are neither imitable nor substitutable. Nevertheless, the unique value of SC agility is based on operating the bundle of SC agility practices. The research findings reveal that the achievement of SC agility is affected by a complementary set of agility practices..

In China, a developing country, companies continue to strive in a macro environment with dramatic transitions (Cai et al., 2010). The country's electronics industry is currently experiencing dramatic growth. Although the industry is filled with opportunity, how to leverage the risks from the external environment is still a major issue. From the perspective of managers in the Chinese electronics companies, SC agility is regarded as a key capacity to improve firm performance. SC agility could be the competitive advantage that enables electronics companies to respond rapidly to uncertainty from both the demand side and the 
supply side.

\section{Managerial Implications and Future Research}

\subsection{Managerial Implications}

This study also has important managerial implication. We suggest that SC agility should be considered comprehensively as requiring not only internal flexibility, but also external coordination (such as acting as integrated supply chain) in order to provide information and knowledge in a timely fashion. Therefore, this study suggests that managers should work closely with their external partners within the supply chain to achieve SC agility. In addition, we highlight the need for executives to actively seek knowledge externally from their suppliers and customers. For example, managers can acquire knowledge externally through the engagement of customers and suppliers in product design; this will give them access to knowledge about the most up-to-date market demand and upstream supplier competence.

Moreover, the validation of the second order model of SC agility, which comprise customer responsiveness, demand response and joint planning, provide significant implication to the practice. Since, if managers operate the three components of SC agility as a bundle, the joint operation costs could be less than the sum of individually operating these practices. Moreover, the three components of SC agility can create a synergy effect on firm performance. A practical implication of this is that managers should not consider the three components of SC agility in isolation, but should treat them as a complementary set. If a company is separately involved in customer response, demand response and joint planning, then SC agility cannot realize the sub-additive synergies.

Drawing from the analysis of the mediation role of SC agility, we would like to remind managers that they might not expect to significantly improve the firm performance through simply applying the supply chain management practices like SC integration or external learning. The implementation of the SC integration or external learning should first impact on fostering the SC agility along three sub dimensions - customer responsiveness, demand 
response and joint planning that then positively influence on firm performance. Although the extensive literatures have highlighted the direct effect of those "legendary" management practices (such as SC integration) on firm performance, managers should not underestimate the complexity and difficulty of their implementation. As in the context of electronics industry, succeeding in external learning and SC integration might not determine the outstanding performance of firm until enhancing the SC agility.

\subsection{Limitations and Future Research}

This study examines the relationship between SC agility and two determinants: external learning and supply chain integration. We also strive to identify the impact of SC agility on firm performance. A conceptual framework is developed to investigate the interrelationship among different constructs, where both of the antecedents (i.e. external learning and supply chain integration) are hypothesized as having direct impact on SC agility and SC agility is believed to enhance firm performance. In order to validate the conceptual model, we adopt SEM analysis using 266 data samples in the Chinese electronics industry. The results suggest that both proposed antecedents are positively and significantly associated with SC agility. At the same time, firm performance is positively affected by SC agility. We find a full mediating effect of SC agility within the causations between firm performance and SC integration and external learning. In addition, the results indicate a synergy effect of SC agility on firm performance, which leads us to suggest that managers should operate SC agility as a bundle of different supply chain practices, comprising demand response, customer response and joint planning. This study fills a research gap by identifying the roles of different antecedents of SC agility, which had not been fully investigated in the previous literature, particularly with regard to external learning. The research findings also provide some practical suggestions to managers on how to achieve SC agility.

There are several limitations to our study, which could be addressed by further investigations. Firstly, this study only considers the external coordination factors of SC agility, whereas future studies will benefit from exploring the impact of internal operational capacity (Patel et al., 2012), such as internal learning, manufacturing flexibility, and labour flexibility, on SC agility. Secondly, the use of a cross-sectional sample reflects only the current effects, making 
it hard to rigorously test the casual relationships between the constructs of our study. We suggest that researchers could conduct a longitudinal study to investigate the dynamic nature of SC agility, which might evolve over time. Thirdly, this study controls for only one firm characteristic, company size; future research could include additional variables. Forthly, the future research should investigate the potential effect of the external learning on SC integration by adopting different methods in other industrial context. In addition, although there are extensive empirical studies using the self-reporting data for measuring the firm performance (FP1 to FP5 in this study), the potential threat to the validity of firm performance should not be ignored by the future researches. It can be further improved by adopting multi-informant approach or adopt the independently audited and published financial data to measure the firm performance for avoiding the data validity problem. Last but not least, our sample of Chinese electronic industry may limit the generalizability of the results. Therefore, future research could investigate our proposed model in different industry context. 


\section{Reference}

Agarwal, A., Shankar, R. and Tiwari, M. K. (2007), "Modeling agility of supply chain", Industrial Marketing Management, Vol. 36 No. 4, pp. 443-457.

Alegre, J. and Chiva, R. (2008), "Assessing the impact of organizational learning capability on product innovation performance: An empirical test", Technovation, Vol. 28 No. 6, pp. 315326.

Antonacopoulou, E. and Chiva, R. (2007), "The social complexity of organizational learning: The dynamics of learning and organizing", Management Learning, Vol. 38 No. 3, pp. 277-295.

Armistead, C. and Mapes, J. (1993), "The impact of supply chain integration on operating performance", Logistics Information Management, Vol. 6 No. 4, pp. 9-14.

Armstrong, J. S. and Overton, T. S. (1977), "Estimating Nonresponse Bias in Mail Surveys", Journal of Marketing Research, Vol. 14 No. 3, pp. 396-402.

Bao, Y. C., Chen, X. Y. and Zhou, K. Z. (2012), "External learning, market dynamics, and radical innovation: Evidence from China's high-tech firms", Journal of Business Research, Vol. 65 No. 8, pp. 1226-1233.

Barney, J. (1991), "Firm Resources and Sustained Competitive Advantage", Journal of Management, Vol. 17 No. 1, pp. 99-120.

Baron, R. M. and Kenny, D. A. (1986), "The Moderator Mediator Variable Distinction in Social Psychological-Research - Conceptual, Strategic, and Statistical Considerations", Journal of Personality and Social Psychology, Vol. 51 No. 6, pp. 1173-1182.

Bennet, A. and David, B. (2004), The partnership between organizational learning and knowledge management., Springer, Berlin Heidelberg.

Bernardes, E. S. and Hanna, M. D. (2009), "A theoretical review of flexibility, agility and responsiveness in the operations management literature Toward a conceptual definition of customer responsiveness", International Journal of Operations \& Production Management, Vol. 29 No. 1-2, pp. 30-53.

Bierly, P. E., Paul, E. and Daly, P. S. (2007), "Sources of external organisational learning in small manufacturing firms", International Journal of Technology Management, Vol. 38 No. 1-2, pp. 45-68.

Bollen, K. and Stine, R. (1990), "Direct and Indirect Effects: Classical and Bootstrap Estimates of Variability", Sociological Methodology, Vol. 20, pp. 115-140.

Bollen, K. A. (1989), Structral Equations with Latent Varaibles, Wiley, New York.

Braunscheidel, M. J. and Suresh, N. C. (2009), "The organizational antecedents of a firm's supply chain agility for risk mitigation and response", Journal of Operations Management, Vol. 27 No. 2, pp. 119-140.

Brislin, R. (1980), Translation and content analysis of oral and written material.

Brown, T. (2006), Confirmatory Factor Analysis for Applied Research, The Guilford Press, New York.

Browne, M. and Cudeck, R. (2003), "Alternative ways of assessing model fit", in Bollen, K. a. (Ed.), Testing Structral Equation Models. Sage Publications, London, UK.

Cai, S. H., Jun, M. and Yang, Z. L. (2010), "Implementing supply chain information integration in China: The role of institutional forces and trust", Journal of Operations Management, Vol. 28 No. 3, pp. 257-268.

Calantone, R. J., Cavusgil, S. T. and Zhao, Y. S. (2002), "Learning orientation, firm innovation capability, and firm performance", Industrial Marketing Management, Vol. 31 No. 6, pp. 515-524. 
Cao, M. and Zhang, Q. Y. (2011), "Supply chain collaboration: Impact on collaborative advantage and firm performance", Journal of Operations Management, Vol. 29 No. 3, pp. 163-180.

Chen, I. J., Paulraj, A. and Lado, A. A. (2004), "Strategic purchasing, supply management, and firm performance", Journal of Operations Management, Vol. 22 No. 5, pp. 505-523.

Chiang, C. Y., Kocabasoglu-Hillmer, C. and Suresh, N. (2012), "An empirical investigation of the impact of strategic sourcing and flexibility on firm's supply chain agility", International Journal of Operations \& Production Management, Vol. 32 No. 1-2, pp. 49-78.

Chin, W. W. (1998), "Issues and opinion on structural equation modeling", Mis Quarterly, Vol. 22 No. 1, pp. 7-16.

Christopher, M. (2000), "The agile supply chain - Competing in volatile markets", Industrial Marketing Management, Vol. 29 No. 1, pp. 37-44.

Christopher, M., Robert, L. and Helen, P. (2013), "Creating agile supply chains in the fashion industry", International Journal of Retail \& Distribution Management. Vol. 32 No. 8, pp. 367-376

Conner, K. (1991), "A historical comparison of resource-based theory and five schools of thought within industrial economics: Do we have a new theory of the firm?", Journal of Management, Vol. 17 No. 1, pp. 121-154.

Council, S. C. (2004), "The Supply Chain Operations Reference (SCOR) Model", in.

Cousins, P. D., Lawson, B. and Squire, B. (2008), "Performance measurement in strategic buyersupplier relationships: The mediating role of socialization mechanisms", International Journal of Operations \& Production Management, Vol. 28 No. 3, pp. 238-258.

Cua, K. O., McKone, K. E. and Schroeder, R. G. (2001), "Relationships between implementation of TQM, JIT, and TPM and manufacturing performance", Journal of Operations Management, Vol. 19 No. 6, pp. 675-694.

Danese, P., Romano, P. and Formentini, M. (2013), "The impact of supply chain integration on responsiveness: The moderating effect of using an international supplier network", Transportation Research Part E-Logistics and Transportation Review, Vol. 49 No. 1, pp. 125-140.

Day, G. S. (1994), "The Capabilities of Market-Driven Organizations", Journal of Marketing, Vol. 58 No. 4, pp. 37-52.

Day, G. S. (1994), "Continuous Learning About Markets", California Management Review, Vol. 36 No. 4, pp. 9-31.

Devaraj, S., Krajewski, L. and Wei, J. C. (2007), "Impact of eBusiness technologies on operational performance: The role of production information integration in the supply chain", Journal of Operations Management, Vol. 25 No. 6, pp. 1199-1216.

Dillman, D. a. (1978), Mail and telephone surveys, Wiley Interscience.

Doty, D. H. and Click, W. (1998), "Common Methods Bias: Does Common Methods Variance Really Bias Results?", Organizational Research Methods.

Dove, R. (1996), "Agile supply chain management", Automative Production., Vol. 108 No. 4, pp. 1617.

Droge, C., Vickery, S. K. and Jacobs, M. A. (2012), "Does supply chain integration mediate the relationships between product/process strategy and service performance? An empirical study", International Journal of Production Economics, Vol. 137 No. 2, pp. 250-262.

Dumaine, B. (1994), "Mr Learning Organization", Fortune, Vol. 130 No. 8, pp. 147

Dyer, J. H. and Nobeoka, K. (2000), "Creating and managing a high-performance knowledge-sharing network: The Toyota case", Strategic Management Journal, Vol. 21 No. 3, pp. 345-367.

Fliedner, G. and Vokuraka, R. J. (1997), "Agility: competitive weapon of the 1990s and beyond?", Production and Inventory Management Journal, Vol. 38 No. 3, pp. 19. 
Flynn, B. B., Huo, B. F. and Zhao, X. D. (2010), "The impact of supply chain integration on performance: A contingency and configuration approach", Journal of Operations Management, Vol. 28 No. 1, pp. 58-71.

Fornell, C. and Larcker, D. F. (1981), "Evaluating Structural Equation Models with Unobservable Variables and Measurement Error", Journal of Marketing Research, Vol. 18 No. 1, pp. 39-50.

Frohlich, M. T. and Westbrook, R. (2001), "Arcs of integration: an international study of supply chain strategies", Journal of Operations Management, Vol. 19 No. 2, pp. 185-200.

Gerbing, D. W. and Anderson, J. C. (1988), "An Updated Paradigm for Scale Development Incorporating Unidimensionality and Its Assessment on JSTOR", Journal of Marketing Research, Vol. 25 No. 2, pp. 186-192.

Gerwin, D. (1993), "Manufacturing Flexibility - a Strategic Perspective", Management Science, Vol. 39 No. 4, pp. 395-410.

Gligor, D. M. (2014), "The role of demand management in achieving supply chain agility", Supply Chain Management-an International Journal, Vol. 19 No. 5-6, pp. 577-591.

Gligor, D. M., Esmark, C. L. and Holcomb, M. C. (2015), "Performance outcomes of supply chain agility: When should you be agile?", Journal of Operations Management, Vol. 33-34, pp. 7182.

Gligor, D. M. and Holcomb, M. C. (2012), "Understanding the role of logistics capabilities in achieving supply chain agility: a systematic literature review", Supply Chain Management-an International Journal, Vol. 17 No. 4, pp. 438-453.

Grant, R. M. and Badenfuller, C. (1995), "A knowledge-based theory of inter-firm collaboration", Best Papers Proceedings - Fifty-Fifth Annual Meeting of the Academy of Management, pp. 17-21.

Hair, J. F., Black, W. C., Babin, B. J. and Anderson, R. E. (2006), Multivariate data analysis (Vol. 6). Pearson, Upper Saddle River, NJ.

Handfield, R. B. and Nichols, E. L. (1999), Introduction to Supply Chain Management, PrenticeHall, Upper Saddle River, NJ.

Harman, H. H. (1967), Mordern Factor Analysis, University of Chicago Press, Chicago, Illinois.

Hayes, A. (2013), Introduction to mediation, moderation, and conditional process analysis: A regression-based approach, Guilford Press.

Hendricks, K. B. and Singhal, V. R. (2001), "Firm characteristics, total quality management, and financial performance", Journal of Operations Management, Vol. 19 No. 3, pp. 269-285.

Huang, X. W., Kristal, M. M. and Schroeder, R. G. (2008), "Linking learning and effective process implementation to mass customization capability", Journal of Operations Management, Vol. 26 No. 6, pp. 714-729.

Humphreys, P., Cadden, T., Wen-Li, L. and McHugh, M. (2011), "An investigation into supplier development activities and their influence on performance in the Chinese electronics industry", Production Planning \& Control, Vol. 22 No. 2, pp. 137-156.

Huo, B. F. (2012), "The impact of supply chain integration on company performance: an organizational capability perspective", Supply Chain Management-an International Journal, Vol. 17 No. 6, pp. 596-610.

Kassinis, G. I. and Soteriou, A. C. (2003), "Greening the service profit chain: The impact of environmental management practices", Production and Operations Management, Vol. 12 No. 3, pp. 386-403.

Kidd, P. T. (1994), Agile Manufacturing: Forging New Frontiers, Addison-Wseley, Reading, MA.

Kidd, P. T. (2000), "Two definitions of agility", available at: http://www.cheshirehenbury.com (accessed).

Kim, M. and Jim, C. (2011), "Japan quake tests supply chain from chips to ships", available at: 
http://www.reuters.com/article/2011/03/14/us-japan-quake-supplychainidUSTRE72D1FQ20110314 (accessed 03-FEB-2015 2015).

Kim, S. W. (2006), "Effects of supply chain management practices, integration and competition capability on performance", Supply Chain Management-an International Journal, Vol. 11 No. 3, pp. 241-248.

Kim, S. W. (2009), "An investigation on the direct and indirect effect of supply chain integration on firm performance", International Journal of Production Economics, Vol. 119 No. 2, pp. 328346.

Kleindorfer, P. R. and Saad, G. H. (2005), "Managing disruption risks in supply chains", Production and Operations Management, Vol. 14 No. 1, pp. 53-68.

Krause, D. R. and Scannell, T. V. (2002), "Supplier development practices: product and service based industry comparisons.", Journal of Supply Chain Management, Vol. 38, pp. 13-21.

Kristal, M. M., Huang, X. W. and Schroeder, R. G. (2010), "The effect of quality management on mass customization capability", International Journal of Operations \& Production Management, Vol. 30 No. 9-10, pp. 900-922.

Laursen, K. and Salter, A. (2006), "Open for innovation: The role of openness in explaining innovation performance among UK manufacturing firms", Strategic Management Journal, Vol. 27 No. 2, pp. 131-150.

Lee, H. L. (2004), "The triple-A supply chain", Harvard Business Review, Vol. 82 No. 10, pp. 102-+.

Li, S. H. and Lin, B. S. (2006), "Accessing information sharing and information quality in supply chain management", Decision Support Systems, Vol. 42 No. 3, pp. 1641-1656.

Linderman, K., Schroeder, R. G., Zaheer, S., Liedtke, C. and Choo, A. S. (2004), "Integrating quality management practices with knowledge creation processes", Journal of Operations Management, Vol. 22 No. 6, pp. 589-607.

Love, P. E., Irani, Z., Cheng, e. and Li, H. (2002), "A model for supporting inter-organizational relations in the supply chain.", Engineering Construction and Acrchitectual Management, Vol. 9 No. 1, pp. 2-15.

Madhok, A. and Tallman, S. B. (1998), "Resources, transactions and rents: Managing value through interfirm collaborative relationships", Organization Science, Vol. 9 No. 3, pp. 326-339.

Marsh, H. W. and Hocevar, D. (1985), "Application of Confirmatory Factor-Analysis to the Study of Self-Concept - 1st Order and Higher-Order Factor Models and Their Invariance across Groups", Psychological Bulletin, Vol. 97 No. 3, pp. 562-582.

Mason, S., Cole, M., Ulrey, B. and Yan, L. (2002), "Improving electronics manufacturing supply chain agility through outsourcing.", International Journal of Physical Distribution \& Logistics Management, Vol. 32 No. 7, pp. 610-620.

Matthing, J., Sanden, B. and Edvardsson, B. (2004), "New service development: learning from and with customers", International Journal of Service Industry Management, Vol. 15 No. 5, pp. 479-498.

Merschmann, U. and Thonemann, U. W. (2011), "Supply chain flexibility, uncertainty and firm performance: An empirical analysis of German manufacturing firms", International Journal of Production Economics, Vol. 130 No. 1, pp. 43-53.

Mishra, A. A. and Shah, R. (2009), "In union lies strength: Collaborative competence in new product development and its performance effects", Journal of Operations Management, Vol. 27 No. 4, pp. 324-338.

Nagel, R. N. and Dove, R. (1991), 21st century manufacturing enterprise strategy: An industry-lead view., DIANE Publishing.

Narasimhan, R. and Kim, S. W. (2001), "Information system utilization strategy for supply chain integration", Journal of Business Logistics, Vol. 22 No. 2. 
Narasimhan, R. and Kim, S. W. (2002), "Effect of supply chain integration on the relationship between diversification and performance: evidence from Japanese and Korean firms", Journal of Operations Management, Vol. 20 No. 3, pp. 303-323.

Ngai, E. W. T., Chau, D. C. K. and Chan, T. L. A. (2011), "Information technology, operational, and management competencies for supply chain agility: Findings from case studies", Journal of Strategic Information Systems, Vol. 20 No. 3, pp. 232-249.

Nonaka, I. (1991), "The Knowledge-Creating Company", Harvard Business Review, Vol. 69 No. 6, pp. 96-104.

Nonaka, I. (1994), "A Dynamic Theory of Organizational Knowledge Creation", Organization Science, Vol. 5 No. 1, pp. 14-37.

O'Leary-Kelly, S. W. and Vokuraka, R. J. (1998), "The empirical assessment of construct validity", Journal of Operations Management, Vol. 16 No. 4, pp. 387-405.

Patel, P. C., Terjesen, S. and Li, D. (2012), "Enhancing effects of manufacturing flexibility through operational absorptive capacity and operational ambidexterity", Journal of Operations Management, Vol. 30 No. 3, pp. 201-220.

Podsakoff, P. M., MacKenzie, S. B., Lee, J. Y. and Podsakoff, N. P. (2003), "Common method biases in behavioral research: A critical review of the literature and recommended remedies", Journal of Applied Psychology, Vol. 88 No. 5, pp. 879-903.

Podsakoff, P. M. and Organ, D. W. (1986), "Self-Reports in Organizational Research - Problems and Prospects", Journal of Management, Vol. 12 No. 4, pp. 531-544.

Power, D. (2005), "Supply chain management integration and implementation: a literature review", Supply Chain Management-an International Journal, Vol. 10 No. 3-4, pp. 252-263.

Prater, E., Biehl, M. and Smith, M. A. (2001), "International supply chain agility - Tradeoffs between flexibility and uncertainty", International Journal of Operations \& Production Management, Vol. 21 No. 5-6, pp. 823-839.

Putzger, I. (1998), "All the ducks in a row", World Trade, Vol. 11 No. 9, pp. 54-56.

Quinn, R. D., Causey, G. C., Merat, F. L., Sargent, D. M., Barendt, N. A., Newman, W. S., Velasco, V. B., Podgurski, A., Jo, J. Y., Sterling, L. S. and Kim, Y. W. (1997), "An agile manufacturing workcell design", Iie Transactions, Vol. 29 No. 10, pp. 901-909.

Rosenzweig, E. D., Roth, A. V. and Dean, J. W. (2003), "The influence of an integration strategy on competitive capabilities and business performance: An exploratory study of consumer products manufacturers", Journal of Operations Management, Vol. 21 No. 4, pp. 437-456.

Rungtusanatham, M., Miller, J. W. and Boyer, K. K. (2014), "Theorizing, testing, and concluding for mediation in SCM research: Tutorial and procedural recommendations", Journal of Operations Management, Vol. 32 No. 3, pp. 99-113.

Saldanha, J. P., Hunt, C. S. and Mello, J. E. (2013), "Driver Management That Drives Carrier Performance", Journal of Business Logistics, Vol. 34 No. 1, pp. 15-32.

Schroeder, R. G., Bates, K. A. and Junttila, M. A. (2002), "A resource-based view of manufacturing strategy and the relationship to manufacturing performance", Strategic Management Journal, Vol. 23 No. 2, pp. 105-117.

Sharifi, H. and Zhang, Z. (1999), "A methodology for achieving agility in manufacturing organisations: An introduction", International Journal of Production Economics, Vol. 62 No. $1-2$, pp. 7-22.

Sheffi, Y. (2001), "Supply Chain Management under the Threat of International Terrorism.", The International Journal of Logistics Management, Vol. 12 No. 2, pp. 1-11.

Slater, S. F. and Narver, J. C. (1995), "Market Orientation and the Learning Organization", Journal of Marketing, Vol. 59 No. 3, pp. 63-74.

Spekman, R. E., Spear, J. and Kamauff, J. (2002), "Supply chain competency: learning as a key 
component", Supply Chain Management: An International Journal, Vol. 7 No. 1, pp. 41-55. Spender, J. C. (1996), "Making knowledge the basis of a dynamic theory of the firm", Strategic Management Journal, Vol. 17, pp. 45-62.

Sveiby, K. E. (2001), "A knowledge-based theory of the firm to guide in strategy formulation", Journal of intellectual capital, Vol. 2 No. 4, pp. 344-358.

Swafford, P. M., Ghosh, S. and Murthy, N. (2006), "The antecedents of supply chain agility of a firm: Scale development and model testing", Journal of Operations Management, Vol. 24 No. 2, pp. 170-188.

Swafford, P. M., Ghosh, S. and Murthy, N. (2008), "Achieving supply chain agility through IT integration and flexibility", International Journal of Production Economics, Vol. 116 No. 2, pp. 288-297.

Tanriverdi, H. and Venkatraman, N. (2005), "Knowledge relatedness and the performance of multibusiness firms", Strategic Management Journal, Vol. 26 No. 2, pp. 97-119.

Tippins, M. J. and Sohi, R. S. (2003), "IT competency and firm performance: Is organizational learning a missing link?", Strategic Management Journal, Vol. 24 No. 8, pp. 745-761.

Tolone, W. J. (2000), "Virtual situation rooms: connecting people across enterprises for supply-chain agility", Computer-Aided Design, Vol. 32 No. 2, pp. 109-117.

Trkman, P. and McCormack, K. (2009), "Supply chain risk in turbulent environments-A conceptual model for managing supply chain network risk", International Journal of Production Economics, Vol. 119 No. 2, pp. 247-258.

Tunc, E. A. and Gupta, J. n. (1993), "Is time a competitive weapon among manufacturing firms?", International Journal of Operations \& Production Management, Vol. 13 No. 3, pp. 4-12.

van der Vaart, T. and van Donk, D. P. (2008), "A critical review of survey-based research in supply chain integration", International Journal of Production Economics, Vol. 111 No. 1, pp. 4255.

van Hoek, R. I., Harrison, A. and Christopher, M. (2001), "Measuring agile capabilities in the supply chain", International Journal of Operations \& Production Management, Vol. 21 No. 1-2, pp. 126-147.

Vickery, S. K., Jayaram, J., Droge, C. and Calantone, R. (2003), "The effects of an integrative supply chain strategy on customer service and financial performance: an analysis of direct versus indirect relationships", Journal of Operations Management, Vol. 21 No. 5, pp. 523-539.

Ward, P. T., Duray, R., Leong, G. K. and Sum, C. C. (1995), "Business environment, operations strategy, and performance: An empirical study of Singapore manufacturers", Journal of Operations Management, Vol. 13 No. 2, pp. 99-115.

Wernerfelt, B. (1984), "A Resource-Based View of the Firm", Strategic Management Journal, Vol. 5 No. 2, pp. 171-180.

Yang, C. H., Lin, H. L. and Li, H. Y. (2013), "Influences of production and R\&D agglomeration on productivity: Evidence from Chinese electronics firms", China Economic Review, Vol. 27, pp. 162-178.

Yusuf, Y. Y., Gunasekaran, A., Musa, A., Dauda, M., El-Berishy, N. M. and Cang, S. (2014), "A relational study of supply chain agility, competitiveness and business performance in the oil and gas industry", International Journal of Production Economics, Vol. 147, pp. 531-543.

Yusuf, Y. Y., Sarhadi, M. and Gunasekaran, A. (1999), "Agile manufacturing: The drivers, concepts and attributes", International Journal of Production Economics, Vol. 62 No. 1-2, pp. 33-43.

Zhao, L., Huo, B. F., Sun, L. Y. and Zhao, X. D. (2013), "The impact of supply chain risk on supply chain integration and company performance: a global investigation", Supply Chain Management-an International Journal, Vol. 18 No. 2, pp. 115-131.

Zhao, X. D., Huo, B. F., Flynn, B. B. and Yeung, J. H. Y. (2008), "The impact of power and 
relationship commitment on the integration between manufacturers and customers in a supply chain", Journal of Operations Management, Vol. 26 No. 3, pp. 368-388.

Zhao, X. D., Huo, B. F., Selen, W. and Yeung, J. H. Y. (2011), "The impact of internal integration and relationship commitment on external integration", Journal of Operations Management, Vol. 29 No. 1-2, pp. 17-32. 